Research Article

\title{
Chemical composition and antigenotoxic properties of Lippia alba essential oils
}

\author{
Molkary Andrea López ${ }^{1}$, Elena E. Stashenko ${ }^{2}$ and Jorge Luis Fuentes ${ }^{1,2}$ \\ ${ }^{1}$ Microbiology and Environmental Mutagenesis Laboratory, Biology School, Faculty of Sciences, \\ Industrial University of Santander, Bucaramanga, Colombia. \\ ${ }^{2}$ Research Center for Biomolecules, Research Center of Excellence, Industrial University of Santander, \\ Bucaramanga, Colombia.
}

\begin{abstract}
The present work evaluated the chemical composition and the DNA protective effect of the essential oils (EOs) from Lippia alba against bleomycin-induced genotoxicity. EO constituents were determined by Gas Chromatography/Mass Spectrometric (GC-MS) analysis. The major compounds encountered being citral (33\% geranial and $25 \%$ neral), geraniol $(7 \%)$ and trans- $\beta$-caryophyllene $(7 \%)$ for L. alba specimen COL512077, and carvone (38\%), limonene (33\%) and bicyclosesquiphellandrene (8\%) for the other, COL512078. The genotoxicity and antigenotoxicity of EO and the compounds citral, carvone and limonene, were assayed using the SOS Chromotest in Escherichia coli. The EOs were not genotoxic in the SOS chromotest, but one of the major compound (limonene) showed genotoxicity at doses between 97 and $1549 \mathrm{mM}$. Both EOs protected bacterial cells against bleomycin-induced genotoxicity. Antigenotoxicity in the two $L$. alba chemotypes was related to the major compounds, citral and carvone, respectively. The results were discussed in relation to the chemopreventive potential of $L$. alba EOs and its major compounds.
\end{abstract}

Key words: Lippia alba, essential oil, antigenotoxicity, bleomycin, SOS chromotest.

Received: September 30, 2010; Accepted: March 23, 2011.

\section{Introduction}

Lippia alba (Mill.) N.E. Brown (Verbenaceae), an aromatic shrub reaching $1.7 \mathrm{~m}$ high, is distributed throughout the Caribbean, South and Central America and Tropical Africa. The species is mainly used in folk medicine against digestive and respiratory ailments, but also as a sedative, analgesic, anti-inflammatory, antipyretic and antihypertensive remedy (Pascual et al., 2001a; Hennebelle et al., 2008a). In Colombia it is popularly known as "Orégano de cerro" (Hill oregano), "Pronto alivio" (ready-relief) and "Curatodo" (all-round cure) depending on the region (Stashenko et al., 2003).

The species $L$. alba is characterized by variability in the chemical composition of the essential oils, depending on the origin of plant material, as well as the stage of the plant and the part selected for distillation of the oil (Zoghbi et al., 1998). Various chemotypes have been proposed (Hennebelle et al., 2006; Oliveira et al., 2006). Based on both the composition and the possible common biosynthetic pathways among the different oils, the existence

Send correspondence to Jorge Luis Fuentes. Microbiology and Environmental Mutagenesis Laboratory, Biology School, Faculty of Sciences, Industrial University of Santander, A.A. 678, Bucaramanga, Colombia. E-mail: jfuentes@uis.edu.co. of at least seven has been indicated (Hennebelle et al., 2008a). These are: chemotype I (citral, linalool and $\beta$-caryophyllene, as the main constituents), chemotype II (tagetenone), chemotype III (limonene and carvone or related monoterpenic ketones), chemotype IV (myrcene), chemotype V ( $\gamma$-terpinene), chemotype VI (camphor-1,8-cineole) and chemotype VII (estragole). In Colombia, L. alba chemotypes I and III, and a combined (I/III) form, not previously reported, have been found.

Various studies on L. alba bioactivities bolster their use in traditional medicine. The essential oils (EOs), either extracts or their constituents, have revealed antiviral, antibacterial, antifungal and antiparasitic activities (Pino-Alea et al., 1996; Abad et al., 1997; Andrighetti-Fröhner et al., 2005; Teixeira-Duarte et al., 2005; de Carvalho and da Fonseca, 2006; Sena-Filho et al., 2006; Paduch et al., 2007; Ara et al., 2009; Arruda et al., 2009; Mesa-Arango et al., 2009; Shukla et al., 2009), thus sustaining their use in the treatment of diseases of microbial origin. Currently, several major compounds from L. alba EOs are used to control food pathogens (Burt, 2004; Rojas-Graü et al., 2007; Teixeira-Duarte et al., 2007; du Plooy et al., 2009; Linde et al., 2009). Moreover, analgesic, anti-inflammatory and sedative effects in mammalian models have been related to cer- 
tain EO major constituents, such as citral, myrcene and limonene (Viana et al., 1998, 2000; Vale et al., 1999). Sedative effects, attributed to non-volatile flavonoids and iridoids (Zétola et al., 2002, Hennebelle et al., 2008b), were also encountered with $L$. alba ethanol extracts. Furthermore, aqueous extracts also reduced cardiac rate and gastric ulceration induced by indomethacin in rats (Pascual et al., 2001b; Gazola et al., 2004).

In a previous work (Vicuña et al., 2010), the importance of EOs as sources of antitumor, anti-carcinogenic and chemopreventive agents, was emphasized. Although the chemopreventive properties of $L$. alba terpenoids, such as carvone, geraniol, limonene, and perillyl alcohol have been well-documented (He et al., 1997; Crowell, 1999; Uedo et al., 1999; de Carvalho and da Fonseca, 2006; Paduch et al., 2007; Patil et al., 2009; Rabi and Bishayee, 2009), little is known about the chemopreventive potential of other $L$. alba EO constituents, for example, citral (Connor, 1991; Nakamura et al., 2003; Seo et al., 2008).

After determining the EOs composition of the two $L$. alba specimens by GC-MS analysis, their specific antigenotoxic activity against the clastogenic mutagen, bleomycin, was evaluated by using the SOS Chromotest (Quillardet et al., 1982). The antigenotoxic properties of the major EO constituents (citral, carvone and limonene) were also studied and their activity compared with the antigenotoxic standard compound Trolox. Our work provides new insights into chemoprevention by L. alba EO major compounds.

\section{Materials and Methods}

\section{Chemicals}

Sodium sulfate and dichloromethane were purchased from Aldrich Chemical Co. Inc. (Milwaukee, WI, USA). High purity gases (helium, nitrogen, hydrogen and air) for chromatography were obtained from AGA-Fano S.A. (Bucaramanga, Colombia). Different standard compounds ( $n$-tetradecane, $n$-alkanes $\left(\mathrm{C}_{8}-\mathrm{C}_{25}\right)$, citral (40:60 neral:geranial), $\mathrm{S}(+)$-carvone and $\mathrm{S}(-)$-limonene), Luria-Bertani (LB) media, and antibiotics (ampicillin, bleomycin and tetracycline) were obtained from Sigma-Aldrich Co. Inc. (Milwaukee, WI, USA). The standard antioxidant compound 6-hydroxy-2,5,7,8-tetramethylchromane-2-carboxylic acid (Trolox) was purchased from Fluka (Steinheim, Germany). The substrates for $\beta$-galactosidase (ortho-nitrophenyl- $\beta$-d-galactopyranoside) and alkaline phosphatase ( $p$-nitrophenylphosphate) were purchased from Merck (Darmstadt, Germany).

\section{Plant material}

L. alba plants were collected from the experimental gardens at CENIVAM Agroindustrial Pilot Complex, located at the Universidad Industrial de Santander campus (Bucaramanga, Colombia). Plant growing conditions were as indicated by Stashenko et al., (2008). Taxonomic identification was undertaken by Dr. José Luis Fernández Alonso (National University, Bogotá, Colombia). The two L. alba specimens (COL512077 and COL512078) were stored at the Colombian National Herbarium.

\section{EO extraction and chromatographic analysis}

Fresh leaves and flowers from L. alba plants were used for EO extraction using the microwave-assisted hydrodistillation method, as described by Stashenko et al., (2004). Briefly, a Clevenger-type hydro-distillation apparatus was placed inside a domestic microwave oven (LG, $1100 \mathrm{~W}, 2.45 \mathrm{GHz}$ ) with a side orifice, through which an external glass condenser linked the 21 -round flask with the plant material (ca. $300 \mathrm{~g}$ ) and water (ca. $0.5 \mathrm{l}$ ) inside the oven. The oven was operated for $40 \mathrm{~min}(4 \times 10 \mathrm{~min})$ at full power, which caused water to boil vigorously and reflux. Essential oil was decanted from the condensate, and then dried with anhydrous sodium sulfate. For chromatographic analysis, neat essential oil $(50 \mu \mathrm{L})$ and $n$-tetradecane $(0.5 \mu \mathrm{L})$ were dissolved in $1 \mathrm{~mL}$ of dichloromethane (Chromatography-grade reagent, Merck, Darmstadt, Germany). EO compound identification was based on chromatogra$\mathrm{phic} /$ spectroscopic analysis, as previously indicated by Vicuña et al., (2010).

\section{Bacterial strains and culture}

The Escherichia coli PQ37 strain, as proposed by Quillardet et al. (1982) for detecting genotoxic carcinogens, was used. The cells, grown overnight at $37^{\circ} \mathrm{C}$, were stired at $100 \mathrm{rpm}$ in Luria-Bertani (LB) medium (10 g tryptone $/ \mathrm{L}, 5 \mathrm{~g}$ yeast extract $/ \mathrm{L}, 10 \mathrm{~g}$ sodium chloride/L, $\mathrm{pH}$ 7.4), supplemented with $50 \mu \mathrm{g} / \mathrm{mL}$ ampicillin and $17 \mu \mathrm{g} / \mathrm{mL}$ tetracycline.

\section{Genotoxicity assay}

The SOS Chromotest, as indicated by Quillardet et al., (1982), was used for genotoxicity assaying. Briefly, overnight-cultures were grown in fresh LB medium (indicated above) until reaching an optical density of $\mathrm{OD}_{600 \mathrm{~nm}}=0.4$. They were then diluted 10 -fold in doublestrength LB medium, and mixed ( $\mathrm{v} / \mathrm{v})$ with a specific substance for identification (EO, citral, carvone and limonene). Pure EOs (density of $900 \mathrm{mg} / \mathrm{mL}$ determined with a BRAND picnometer, Wertheim, Germany) were diluted in distilled water by vigorously stirring to a concentration ranging between 1.7 and $450.0 \mathrm{mg} / \mathrm{mL}$, this including the antioxidant dose as previously indicated (Stashenko et al., 2004). Negative (distilled water) and positive ( $1 \mu \mathrm{g} / \mathrm{mL}$ of bleomycin) controls were always included in each assay. Cells were exposed to substances during $30 \mathrm{~min}$ at $8{ }^{\circ} \mathrm{C}$, and then cultured during $2 \mathrm{~h}$ at $37^{\circ} \mathrm{C}$. The assays for $\beta$-galactosidase and alkaline phosphatase activities were according to Vicuña et al. (2010). 
The genotoxicity criterion applied was the Induction Factor (IF), which, by representing fold induction of the sulA gene in each treatment (EO, mutagen, etc), could be considered as an indirect measure of induced primary DNA damage. The IF was calculated as: IF $=(\beta$-galactosidase $/ a l-$ kaline phosphatase $)_{\mathrm{t}} /$ ( $\beta$-galactosidase/alkaline phosphatase $)_{n t}$, where $t$ and $n t$ are the treated and non-treated cells, respectively.

\section{Antigenotoxicity assay}

Antigenotoxicity was assayed using the co-incubation procedure, as indicated by Fuentes et al., (2006). Although the procedure was basically the same as that of the genotoxicity protocol, the cells were simultaneously cotreated with different concentrations of the tested substances (EO, citral, carvone and limonene) and the mutagen $(1 \mu \mathrm{g} / \mathrm{mL}$ of bleomycin). Antigenotoxicity, i.e., the DNAprotective capacity of the tested substance, was measured as a significant reduction in IF in the combined treatments (substance + bleomycin), and expressed as a percentage of genotoxicity inhibition:

$$
\% \mathrm{GI}=1-\frac{\mathrm{IF}_{\mathrm{co}}-\mathrm{IF}_{\text {basal }}}{\mathrm{IF}_{\text {bleo }}-\mathrm{IF}_{\text {basal }}} \times 100
$$

where $\mathrm{IF}_{\mathrm{co}}$ is the SOS induction factor in co-treated cells (substance + bleomycin), $\mathrm{IF}_{\text {basal }}$ the basal SOS induction factor, and $\mathrm{IF}_{\text {bleo }}$ the SOS induction factor in bleomycintreated cells.

\section{Statistical analysis}

The average values of alkaline phosphatase and IF and the corresponding standard errors were calculated. Normality of the data was tested using the KolmogorovSmirnov test. Variance homogeneity and analysis of variance (ANOVA) tests were also conducted. Mean values were compared using Student's $t$-test. Product-moment (Pearson) correlation analysis was applied for examining dose-response relationships in genotoxicity studies. In all statistical analyses, $\mathrm{p}<0.05$ was considered significant. The STATISTICA software package (Version 6.0, StatSoft Inc (2003), Tulsa, OK, USA) was used for all analyses.

\section{Results}

\section{EO chemical analysis}

L. alba EO compounds, as defined by GC-MS analysis, are listed in Table 1. Essential oil chemical composition in the two $L$. alba specimens was different. In specimen COL512077, oxygenated monoterpenes (70.5\%) were predominant, followed by sesquiterpenes $(13.6 \%)$ and monoterpenes (3.5\%). In specimen COL512078, there were high percentages of oxygenated monoterpenes (49.4\%) and monoterpenes $(36.0 \%)$, followed by sesquiterpenes $(13.6 \%)$. The major compounds in specimen COL512077 were citral (geranial 33\% and neral 25\%), geraniol (7\%) and trans- $\beta$ caryophyllene (7\%), whereas specimen COL512078 was characterized by a high proportion of carvone (38\%), limonene (33\%) and bicyclosesquiphellandrene (8\%) (Figure 1). Based on EO densities and the percentage of chromatogram area for major compounds, compound concentrations were thus estimated: neral $(231 \mathrm{mg} / \mathrm{mL})$, geranial $(302 \mathrm{mg} / \mathrm{mL})$, geraniol $(65 \mathrm{mg} / \mathrm{mL})$, trans $-\beta$-caryophyllene $(59 \mathrm{mg} / \mathrm{mL})$, carvone $(345 \mathrm{mg} / \mathrm{mL})$, limonene $(301 \mathrm{mg} / \mathrm{mL})$ and bicyclosesquiphellandrene $(70 \mathrm{mg} / \mathrm{mL})$. The L. alba EOs studied here were classified as citral (COL512077) and carvone/limonene (COL512078) chemotypes.

\section{Genotoxic and antigenotoxic effects of $L$. alba EOs}

The genotoxicity of $L$. alba EO was assayed before the antigenotoxic effect was investigated. Oils did not increased the IF values in PQ37 Escherichia coli strain indicating that they do not induce the SOS response in E. coli cells (Table 2). Interestingly, a stimulating effect on protein synthesis, measured as alkaline phosphatase activity, was observed with increased EO concentration in the case of
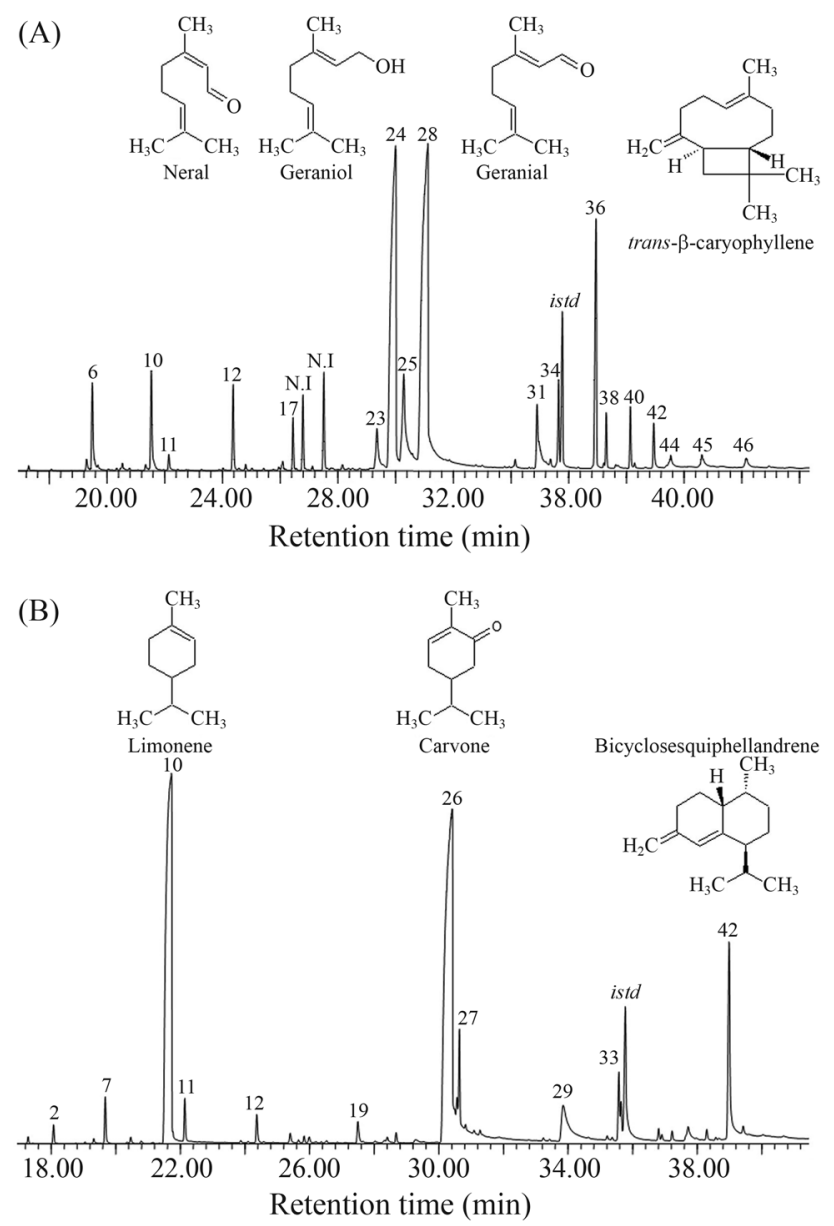

Figure 1 - GC-MS profiles of EO from L. alba specimens, COL512077 (A) and COL512078 (B). Major EO constituents were numbered according to elution order on DB-5MS column indicated in Table 1. 
Table 1 - Chemical composition of the Lippia alba essential oils obtained by microwave-assisted hydrodistillation of each specimen or chemotype.

\begin{tabular}{|c|c|c|c|c|}
\hline \multirow[b]{2}{*}{ No. } & \multirow[b]{2}{*}{ Compounds } & \multirow[b]{2}{*}{$\mathrm{I}_{\mathrm{K}}$} & \multicolumn{2}{|c|}{ Relative amount (\%) } \\
\hline & & & COL512077 (citral) & COL512078 (carvone/limonene) \\
\hline 1 & $\alpha$-pinene & 937 & 0.1 & 0.1 \\
\hline 2 & Camphene & 954 & - & 0.4 \\
\hline 3 & Verbenene & 967 & - & 0.2 \\
\hline 4 & 1-octen-3-ol & 981 & 0.3 & - \\
\hline 5 & $\beta$-pinene-1-octen-3-ol & 982 & - & 0.1 \\
\hline 6 & 6-methyl-5-hepten-2-one & 986 & 2.2 & - \\
\hline 7 & $\beta$-Myrcene & 990 & 0.2 & 1.0 \\
\hline 8 & $\alpha$-phellandrene & 1010 & 0.2 & - \\
\hline 9 & $\rho$-cymene & 1028 & 0.2 & - \\
\hline 10 & Limonene & 1035 & 2.5 & 33.2 \\
\hline 11 & trans- $\beta$-ocimene & 1048 & 0.4 & 1.0 \\
\hline 12 & Linalool & 1101 & 1.8 & 0.7 \\
\hline 13 & trans- $p$-mentha-2,8-diene-1-ol & 1127 & - & 0.3 \\
\hline 14 & cis-limonene oxide & 1138 & - & 0.1 \\
\hline 15 & Hexenyl cis-3-isobutanoate & 1140 & 0.1 & - \\
\hline 16 & cis-p-mentha-2,8-diene-1-ol & 1141 & - & 0.2 \\
\hline 17 & Citronellal & 1153 & 1.0 & - \\
\hline 18 & Rosefuran epoxide & 1171 & 0.1 & - \\
\hline 19 & Borneol & 1180 & - & 0.6 \\
\hline 20 & cis-dihydrocarvone & 1203 & - & 0.3 \\
\hline 21 & trans-dihydrocarvone & 1210 & - & 0.2 \\
\hline 22 & trans-carveol & 1227 & - & 0.3 \\
\hline 23 & Nerol & 1228 & 2.0 & - \\
\hline 24 & Neral & 1246 & 25.4 & - \\
\hline 25 & Geraniol & 1254 & 7.1 & - \\
\hline 26 & Carvone & 1257 & - & 38.1 \\
\hline 27 & Piperitone & 1263 & - & 4.4 \\
\hline 28 & Geranial & 1276 & 33.1 & - \\
\hline 29 & Piperitenone & 1349 & - & 4.3 \\
\hline 30 & Neryl acetate & 1357 & 0.2 & - \\
\hline 31 & Geranyl acetate & 1376 & 2.7 & - \\
\hline 32 & $\alpha$-copaene & 1384 & - & 0.1 \\
\hline 33 & $\beta$-bourbonene $+\beta$-Elemene & 1394 & - & 2.2 \\
\hline 34 & $\beta$-elemene & 1397 & 1.9 & 1.2 \\
\hline 35 & $\beta$-ylangene & 1429 & - & 0.3 \\
\hline 36 & trans- $\beta$-caryophyllene & 1432 & 6.6 & 0.2 \\
\hline 37 & $\beta$-gurjunene & 1441 & - & 0.3 \\
\hline 38 & $\alpha$-guaiene & 1444 & 1.2 & - \\
\hline 39 & trans- $\beta$-farnesene & 1456 & 0.2 & 0.8 \\
\hline 40 & $\alpha$-humulene & 1469 & 1.3 & - \\
\hline 41 & Caryophyllene-9-epi-E & 1473 & 0.1 & 0.3 \\
\hline 42 & Bicyclosesquiphellandrene & 1493 & 1.2 & 7.7 \\
\hline 43 & Bicyclogermacrene & 1507 & - & 0.5 \\
\hline 44 & $\alpha$-bulnesene & 1511 & 0.6 & - \\
\hline 45 & cis- $\alpha$-bisabolene & 1547 & 0.6 & - \\
\hline 46 & Caryophyllene oxide & 1599 & 0.5 & - \\
\hline & Monoterpene hydrocarbons & & 3.5 & 36.0 \\
\hline & Oxygen containing monoterpenes & & 70.5 & 49.4 \\
\hline & Sesquiterpene hydrocarbons & & 13.6 & 13.6 \\
\hline & Oxygen containing sesquiterpenes & & 0.5 & 0.0 \\
\hline & Other not identified & & 5.4 & 0.0 \\
\hline & Total & & 93.5 & 99.1 \\
\hline
\end{tabular}

No., Order of elution is given in DB-5MScolumn, $\mathrm{I}_{\mathrm{K}}$, Values of retention index (Kovats, 1965) calculated from a minimum of three independent chromatograms. 
citral chemotype. Since this did not occur with a water soluble EO fraction (data not shown), apolar compounds in the EO mix are possibly involved.

The antigenotoxic properties of $L$. alba $\mathrm{EO}$ are shown in Table 3. As previously indicated (Vicuña et al., 2010), a dose of $1 \mu \mathrm{g} / \mathrm{mL}$ bleomycin was used for antigenotoxicity assaying. EOs produced a significant decrease in bleomycin-induced genotoxicity (IF values) at doses between 28.1 and $450 \mathrm{mg} / \mathrm{mL}$, though insignificant at those lower. Complete inhibition occurred with both citral and carvone/limonene chemotypes at doses higher than $56.2 \mathrm{mg} / \mathrm{mL}$.

\section{Genotoxic and antigenotoxic effects of $L$. alba EO major constituents}

Genotoxicity of the major EO constituents (citral, carvone and limonene) was also assayed (Table 4). Citral

Table 2 - Genotoxicity study of the $L$. alba EO measured by the SOS chromotest.

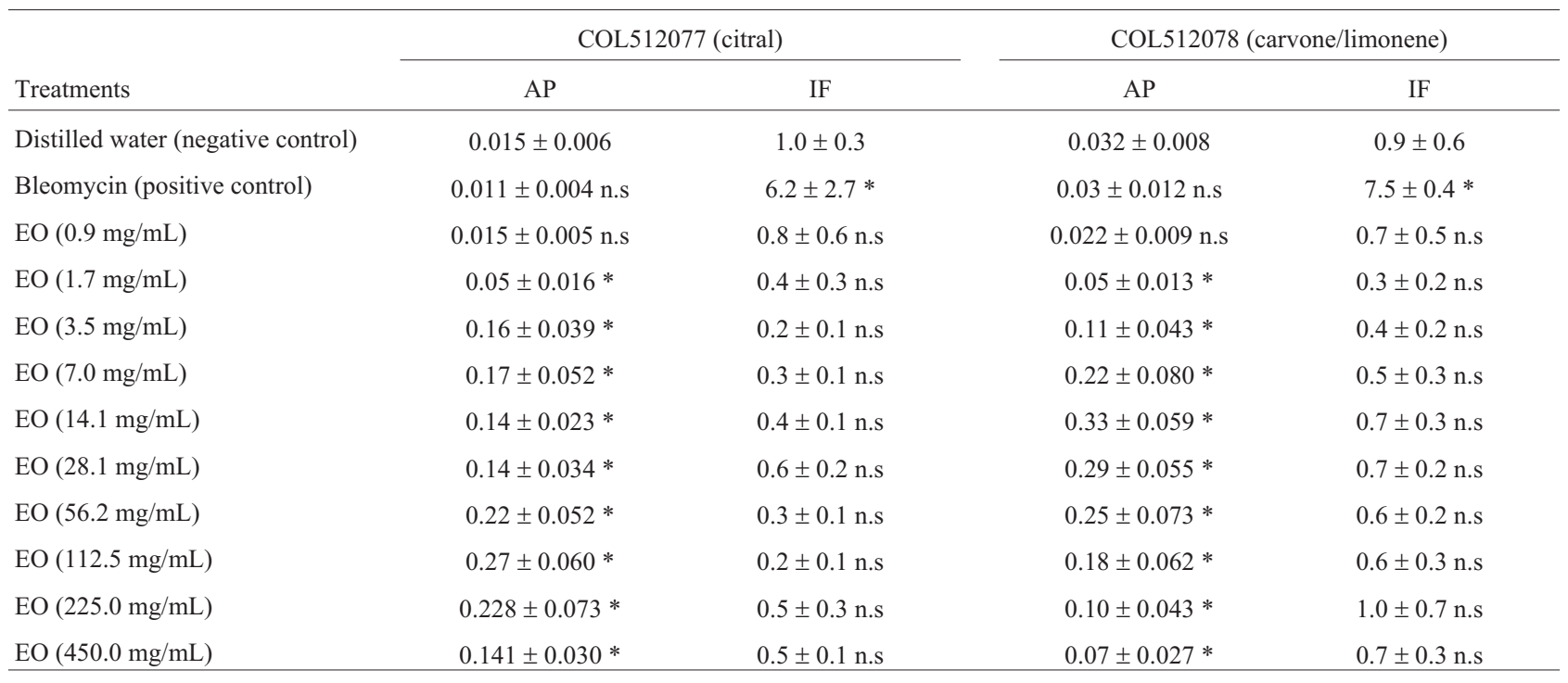

Bleomycin dosage was $1 \mu \mathrm{g} / \mathrm{mL}$. Densities of essential oils were estimated in $900 \mathrm{mg} / \mathrm{mL}$ using a $9.814 \mathrm{~mL}$ BRAND picnometer (Wertheim, Germany). $\dagger$, Average values for direct absorbance measurement of alkaline phosphatase (AP) activity and SOS Induction Factor (IF), from a minimum of three independent experiments with three replicates each, as well as the corresponding standard error, are given. ${ }^{*}$, The significant increase ( $\mathrm{p}<0.05$ ) in negative control was found by Student $t$-testing. n.s., no significant differences were found.

Table 3 - Antigenotoxic effect of L. alba EO against bleomycin-induced DNA damage in PQ37 Escherichia coli cells.

\begin{tabular}{lcc}
\hline & \multicolumn{2}{c}{$\mathrm{IF}^{\dagger}(\% \mathrm{GI})$} \\
\cline { 2 - 3 } Cell treatments & COL512077 (citral) & COL512078 (carvone/limonene) \\
\hline Distilled water (negative control) & $1.0 \pm 0.1$ & $1.0 \pm 0.0$ \\
Bleomycin (positive control) & $5.8 \pm 1.2$ & $5.4 \pm 1.4$ \\
EO $(450.0 \mathrm{mg} / \mathrm{mL})$ & $0.5 \pm 0.1$ & $0.7 \pm 0.3$ \\
EO $(450.0 \mathrm{mg} / \mathrm{mL})+$ Bleomycin & $0.4 \pm 0.1(100 \%) *$ & $0.4 \pm 0.1(100 \%) *$ \\
EO $(225.0 \mathrm{mg} / \mathrm{mL})+$ Bleomycin & $0.5 \pm 0.1(100 \%) *$ & $0.6 \pm 0.2(100 \%) *$ \\
EO $(112.5 \mathrm{mg} / \mathrm{mL})+$ Bleomycin & $0.9 \pm 0.3(100 \%) *$ & $0.5 \pm 0.2(100 \%) *$ \\
EO $(56.2 \mathrm{mg} / \mathrm{mL})+$ Bleomycin & $0.9 \pm 0.5(100 \%) *$ & $0.9 \pm 0.6(100 \%) *$ \\
EO $(28.1 \mathrm{mg} / \mathrm{mL})+$ Bleomycin & $1.9 \pm 0.5(81 \%) *$ & $2.4 \pm 1.6(68 \%) *$ \\
EO $(14.1 \mathrm{mg} / \mathrm{mL})+$ Bleomycin & $5.0 \pm 1.2(17 \%) \mathrm{n} . \mathrm{s}$ & $5.0 \pm 2.3(9 \%) \mathrm{n} . \mathrm{s}$ \\
EO $(7.0 \mathrm{mg} / \mathrm{mL})+$ Bleomycin & $5.0 \pm 1.2(17 \%) \mathrm{n} . \mathrm{s}$ & $6.5 \pm 2.2(0 \%) \mathrm{n} . \mathrm{s}$ \\
EO $(3.5 \mathrm{mg} / \mathrm{mL})+$ Bleomycin & $5.1 \pm 1.2(15 \%) \mathrm{n} . \mathrm{s}$ & $6.6 \pm 1.1(0 \%) \mathrm{n} . \mathrm{s}$ \\
EO $(1.7 \mathrm{mg} / \mathrm{mL})+$ Bleomycin & $5.5 \pm 2.1(6 \%) \mathrm{n} . \mathrm{s}$ & $5.6 \pm 0.8(0 \%) \mathrm{n} . \mathrm{s}$ \\
\hline
\end{tabular}

Bleomycin dosage was $1 \mu \mathrm{g} / \mathrm{mL}$. The densities of essential oils were estimated in $900 \mathrm{mg} / \mathrm{mL}$ using a $9.814 \mathrm{~mL}$ BRAND picnometer (Wertheim, Germany) $\dagger$, SOS Induction Factor (IF) averages from a minimum of three independent experiments with three replicates each, as well as the corresponding standard errors, are given. Percentages of genotoxicity inhibition (\%GI) were calculated as indicated in Materials and Methods. *, significant reduction $(\mathrm{p}<0.05)$ in positive control was found by Student $t$-testing. n.s., no significant reduction was found. 
and carvone did not increase the IF values in PQ37 Escherichia coli strain, indicating that these compounds do not induce the SOS response in E. coli cells. Limonene significantly increased IF values for a dose range between 97 and $1549 \mathrm{mM}$, but no response association was observed by means of Product-moment correlation analysis $(R=-0,06$, n.s) and, therefore, results were considered as non conclusive.

Citral induced a significant reduction in bleomycininduced genotoxicity at a dose of $182 \mathrm{mM}$. Percentages of genotoxicity inhibition (\% GI) increased with citral doses suggesting a direct mode of action for antigenotoxicity of this compound mixture and supporting the results observed with the EO. Carvone and limonene were also antigenotoxic. $\mathrm{S}(+)$-carvone was significantly active only from a dose of $798 \mathrm{mM}$ on, as also very similarly its isomer (R(-)-carvone) (data not shown). Limonene was antigenotoxic from a relatively lower dose $(97 \mathrm{mM})$ on, although GI percentages were always consistently lower than those observed with citral (Table 4). Thus, citral was considered of higher antigenotoxic potential.

Data on antigenotoxicity of positive standard Trolox were also presented for comparison with citral, carvone and limonene. Assayed doses were determined experimentally, since no previous reports on this standard compound and SOS Chromotest were available in the literature. Trolox produced a significant decrease in bleomycin-induced genotoxicity from a dose of $586 \mu \mathrm{M}$, onwards, thus comparatively nearly 90,398 and 1548 times lower than those of citral, carvone and limonene, respectively.

\section{Discussion}

The chemical composition and genotoxic and antigenotoxic properties of $L$. alba EOs obtained by microwave-assisted hydrodistillation, were evaluated. Citral, geraniol, trans- $\beta$-caryophyllene, carvone, limonene and bycyclosesquiphellandrene were identified as the principal components. According to Hennebelle et al. (2008a), there are at least seven chemotypes: I (Citral, linalool and $\beta$-caryophyllene, as the main constituents), II (tagetenone), III (limonene and carvone or related monoterpenic ketones), IV (myrcene), V ( $\gamma$-terpinene), VI (camphor-1,8-cineole) and VII (estragole). So, the two EOs studied here were classified as citral and carvone/limonene chemotypes, thus corresponding to chemotypes I and III, respectively.

Apparently, this is the first report on the genotoxic and antigenotoxic properties of $L$. alba EOs. Under the experimental conditions assayed here (absence of exogenous metabolic activation), the L. alba chemotypes (citral and carvone/limonene) did not induce DNA primary damage in the SOS Chromotest. In addition, EO major constituents as citral and carvone were not genotoxic in the SOS Chromotest. This was in accordance with previous studies using SOS Chromotest, Salmonella/microsome and Drosophila melanogaster SMART assays (Franzios et al., 1997; Gomes-Carneiro et al., 1998; Stammati et al., 1999). For limonene, IF increased at doses between 194 and $774 \mathrm{mM}$, thereby contrasting with the results obtained with EO of the carvone/limonene chemotype. This limonene-effect was possibly masked in the EO by interaction with other constituents, perhaps even carvone itself. Nevertheless, this presumption needs to be tested. A previous study (Vukovic-Gacic et al., 2006) indicated non-mutagenic effects for limonene using Salmonella/microsome assay. As the results so far have been inconclusive, harmonized studies on the genotoxicity of these compounds are now underway in our laboratory.

The antigenotoxic potential of $L$. alba $\mathrm{EO}$ was also shown. Although both the citral and carvone/limonene chemotypes were antigenotoxic against the clastogen bleomycin, citral appears as the most promising source of chemopreventive compounds, apparent by the antigenotoxicity observed in the major constituents (Table 4). The order of antigenotoxic activity for these compounds was found to be citral $>$ carvone $>$ limonene, indicating that citral was the most active compound. Although the chemopreventive properties of $L$. alba terpenoids, as carvone, geraniol, limonene and perillyl alcohol, have already been well-documented (He et al., 1997; Crowell, 1999; Uedo et al., 1999; de Carvalho and da Fonseca, 2006; Paduch et al., 2007; Patil et al., 2009; Rabi and Bishayee, 2009), little is really known as regards citral. Connor (1991) was the first to indicate citral chemopreventive potentiality against skin chemical carcinogenesis in mice. Further experimental evidence lent supported that citral has an ability to suppress oxidative stress, possibly through the induction of endogenous antioxidant proteins, such as phase II xenobiotic metabolizing enzymes, as well as glutatione S-transferase (Nakamura et al., 2003). In addition, it has been recently demonstrated that citral strongly inhibited the CYP2B60 hydroxylase activity (Seo et al., 2008) involved, not only in xenobiotic activation of a wide variety of pro-mutagens, but also in the synthesis of Aflatoxin $\mathrm{B}_{1}$ mycotoxin (Shukla et al., 2009), involved in gastric carcinogenesis. The present work provides new insights into citral and carvone chemoprevention. Since bleomycin genotoxicity involves the generation of radicals in the DNA molecule, which thus induce DNAstrand breakages (Claussen and Long, 1999), it can be expected that the antigenotoxic effect of citral and carvone against bleomycin occurs through radical scavenging mechanisms within the molecule. In fact, Stashenko et al. (2004) have previously demonstrated antioxidant properties for the L. alba carvone/limonene chemotype.

On considering the importance of oxidative damage in carcinogenesis, the antioxidant effect of citral and carvone can be explored as cancer chemopreventive agents against inflammation-related disorders, such as skin and colon cancers. Since carvone and limonene are natural enhancers of transdermal drug delivery by increasing per- 
Table 4 - The genotoxic ${ }^{\dagger}$ effects of citral, carvone and limonene, and respective antigenotoxicity ${ }^{\dagger \dagger}$ against bleomycin-induced DNA damage in PQ37 Escherichia coli cells. Antigenotoxic data on standard compound Trolox are also shown.

\begin{tabular}{|c|c|c|c|}
\hline \multicolumn{2}{|l|}{ Genotoxicity } & \multicolumn{2}{|l|}{ Antigenotoxicity } \\
\hline Cell treatments & $\mathrm{IF}^{\dagger}$ & Cell treatments & $\mathrm{IF}^{\dagger \dagger}(\% \mathrm{GI})$ \\
\hline Distilled water (negative control) & $1.0 \pm 0.1$ & Distilled water (negative control) & $1.0 \pm 0.3$ \\
\hline Bleomycin (positive control) & $7.7 \pm 1.6 *$ & Bleomycin (positive control) & $12.5 \pm 4.4$ \\
\hline Citral $(2915 \mathrm{mM})$ & $0.6 \pm 0.1 \mathrm{n} . \mathrm{s}$ & Citral $(2915 \mathrm{mM})+$ Bleomycin & $0.5 \pm 0.1(100 \%) * *$ \\
\hline Citral (1457 mM) & $0.6 \pm 0.1 \mathrm{n} . \mathrm{s}$ & Citral $(1457 \mathrm{mM})+$ Bleomycin & $0.6 \pm 0.2(100 \%) * *$ \\
\hline Citral (729 mM) & $0.8 \pm 0.2 \mathrm{n} . \mathrm{s}$ & Citral $(729 \mathrm{mM})+$ Bleomycin & $1.0 \pm 0.2(100 \%) * *$ \\
\hline Citral (364 mM) & $1.3 \pm 0.2 \mathrm{n} . \mathrm{s}$ & Citral $(364 \mathrm{mM})+$ Bleomycin & $1.5 \pm 0.3(96 \%) * *$ \\
\hline Citral (182 mM) & $1.2 \pm 0.2 \mathrm{n} . \mathrm{s}$ & Citral $(182 \mathrm{mM})+$ Bleomycin & $1.5 \pm 0.3(96 \%) * *$ \\
\hline Citral $(91 \mathrm{mM})$ & $1.2 \pm 0.2 \mathrm{n} . \mathrm{s}$ & Citral $(91 \mathrm{mM})+$ Bleomycin & $6.9 \pm 2.4(49 \%) n . s$ \\
\hline Citral (45 mM) & $1.2 \pm 0.2 \mathrm{n} . \mathrm{s}$ & Citral $(45 \mathrm{mM})+$ Bleomycin & $17.1 \pm 5.6(0 \%) n . s$ \\
\hline Citral (23 mM) & $1.2 \pm 0.2 \mathrm{n} . \mathrm{s}$ & Citral $(23 \mathrm{mM})+$ Bleomycin & $17.2 \pm 6.8(0 \%)$ n.s \\
\hline Citral (12 mM) & $1.0 \pm 0.3 \mathrm{n} . \mathrm{s}$ & Citral $(12 \mathrm{mM})+$ Bleomycin & $13.9 \pm 6.0(0 \%)$ n.s \\
\hline Distilled water (negative control) & $1.0 \pm 0.1$ & Distilled water (negative control) & $0.9 \pm 0.1$ \\
\hline Bleomycin (positive control) & $5.8 \pm 0.9 *$ & Bleomycin (positive control) & $9.5 \pm 2.8$ \\
\hline Carvone (3192 mM) & $1.2 \pm 0.3 \mathrm{n} . \mathrm{s}$ & Carvone $(3192 \mathrm{mM})+$ Bleomycin & $2.2 \pm 0.5(85 \%) * *$ \\
\hline Carvone (1596 mM) & $1.0 \pm 0.2 \mathrm{n} . \mathrm{s}$ & Carvone $(1596 \mathrm{mM})+$ Bleomycin & $1.7 \pm 0.6(84 \%)^{* *}$ \\
\hline Carvone (798 mM) & $1.3 \pm 0.4 \mathrm{n} . \mathrm{s}$ & Carvone $(798 \mathrm{mM})+$ Bleomycin & $5.2 \pm 1.5(50 \%) * *$ \\
\hline Carvone (399 mM) & $1.4 \pm 0.3 \mathrm{n} . \mathrm{s}$ & Carvone $(399 \mathrm{mM})+$ Bleomycin & $7.6 \pm 3.1(50 \%)$ n.s \\
\hline Carvone (199 mM) & $1.3 \pm 0.1 \mathrm{n} . \mathrm{s}$ & Carvone $(199 \mathrm{mM})+$ Bleomycin & $11.4 \pm 2.5(22 \%)$ n.s \\
\hline Carvone (100 mM) & $1.2 \pm 0.2 \mathrm{n} . \mathrm{s}$ & Carvone $(100 \mathrm{mM})+$ Bleomycin & $11.0 \pm 4.3(0 \%) \mathrm{n} . \mathrm{s}$ \\
\hline Carvone $(50 \mathrm{mM})$ & $1.3 \pm 0.3 \mathrm{n} . \mathrm{s}$ & Carvone $(50 \mathrm{mM})+$ Bleomycin & $9.6 \pm 1.8(0 \%)$ n.s \\
\hline Carvone (25 mM) & $1.1 \pm 0.2 \mathrm{n} . \mathrm{s}$ & Carvone $(25 \mathrm{mM})+$ Bleomycin & $9.7 \pm 2.9(0 \%)$ n.s \\
\hline Carvone (12 mM) & $0.9 \pm 0.2 \mathrm{n} . \mathrm{s}$ & Carvone $(12 \mathrm{mM})+$ Bleomycin & $9.8 \pm 3.6(0 \%)$ n.s \\
\hline Distilled water (negative control) & $1.0 \pm 0.1$ & Distilled water (negative control) & $0.9 \pm 0.2$ \\
\hline Bleomycin (positive control) & $8.9 \pm 1.1 *$ & Bleomycin (positive control) & $7.2 \pm 1.4$ \\
\hline Limonene (3098 mM) & $0.9 \pm 0.3 \mathrm{n} . \mathrm{s}$ & Limonene $(3098 \mathrm{mM})+$ Bleomycin & $2.0 \pm 0.9(82 \%) * *$ \\
\hline Limonene (1549 mM) & $2.0 \pm 0.9 *$ & Limonene $(1549 \mathrm{mM})+$ Bleomycin & $2.0 \pm 0.6(82 \%) * *$ \\
\hline Limonene (774 mM) & $5.7 \pm 1.2 *$ & Limonene $(774 \mathrm{mM})+$ Bleomycin & $4.6 \pm 1.5(41 \%) * *$ \\
\hline Limonene (387 mM) & $4.7 \pm 1.0 *$ & Limonene $(387 \mathrm{mM})+$ Bleomycin & $4.6 \pm 1.5(41 \%) * *$ \\
\hline Limonene (194 mM) & $2.0 \pm 0.3 *$ & Limonene $(194 \mathrm{mM})+$ Bleomycin & $4.7 \pm 1.6(40 \%) * *$ \\
\hline Limonene (97 mM) & $1.6 \pm 0.2 *$ & Limonene $(97 \mathrm{mM})+$ Bleomycin & $4.8 \pm 1.5(38 \%) * *$ \\
\hline Limonene (48 mM) & $1.4 \pm 0.3 \mathrm{n} . \mathrm{s}$ & Limonene $(48 \mathrm{mM})+$ Bleomycin & $5.0 \pm 1.6(35 \%)$ n.s \\
\hline Limonene (24 mM) & $1.4 \pm 0.2 \mathrm{n} . \mathrm{s}$ & Limonene $(24 \mathrm{mM})+$ Bleomycin & $5.6 \pm 1.4(25 \%)$ n.s \\
\hline Limonene (12 mM) & $1.3 \pm 0.3 \mathrm{n} . \mathrm{s}$ & Limonene $(12 \mathrm{mM})+$ Bleomycin & $6.5 \pm 1.2(11 \%) n . s$ \\
\hline Distilled water (negative control) & - & Distilled water (negative control) & $1.1 \pm 0.1$ \\
\hline Bleomycin (positive control) & - & Bleomycin (positive control) & $9.9 \pm 2.1$ \\
\hline Trolox $(4687 \mu \mathrm{M})$ & - & Trolox $(4687 \mu \mathrm{M})+$ Bleomycin & $0.9 \pm 0.3(100 \%) * *$ \\
\hline Trolox $(2344 \mu \mathrm{M})$ & - & Trolox $(2344 \mu \mathrm{M})+$ Bleomycin & $1.1 \pm 0.3(100 \%) * *$ \\
\hline Trolox $(1172 \mu \mathrm{M})$ & - & Trolox $(1172 \mu \mathrm{M})+$ Bleomycin & $0.8 \pm 0.4(100 \%) * *$ \\
\hline Trolox $(586 \mu \mathrm{M})$ & - & Trolox $(586 \mu \mathrm{M})+$ Bleomycin & $2.0 \pm 1.0(90 \%) * *$ \\
\hline Trolox $(293 \mu \mathrm{M})$ & - & Trolox $(293 \mu \mathrm{M})+$ Bleomycin & $7.7 \pm 2.1(25 \%)$ n.s \\
\hline Trolox $(146 \mu \mathrm{M})$ & - & Trolox $(146 \mu \mathrm{M})+$ Bleomycin & $12.9 \pm 2.9(0 \%)$ n.s \\
\hline Trolox $(73 \mu \mathrm{M})$ & - & Trolox $(73 \mu \mathrm{M})+$ Bleomycin & $14.3 \pm 3.0(0 \%)$ n.s \\
\hline Trolox $(37 \mu \mathrm{M})$ & - & Trolox $(37 \mu \mathrm{M})+$ Bleomycin & $10.8 \pm 2.6(0 \%)$ n.s \\
\hline Trolox $(18 \mu \mathrm{M})$ & - & Trolox $(18 \mu \mathrm{M})+$ Bleomycin & $10.8 \pm 2.1(0 \%)$ n.s \\
\hline
\end{tabular}

Bleomycin was always used at a dose of $1 \mu \mathrm{g} / \mathrm{mL}$. According to technical product data (Sigma-Aldrich Co, St. Louis, Missouri, USA), citral, carvone and limonene densities were $0.888,0.959$ and $0.844 \mathrm{~g} / \mathrm{mL}$, respectively. Major compound dose ranges were estimated based on their amount (\%) in the chromatogram and oil density, as indicated in Tables 1 and 2 . Average IF values for genotoxicity ${ }^{\dagger}$ and antigenotoxicity ${ }^{\dagger \dagger}$ from a minimum of three independent experiments with four replicates each, and the corresponding standard error, are given. A substance is classified as nongenotoxic if IF remains $<1.5$, nonconclusive if IF is between 1.5 and 2.0, and genotoxic if IF exceeds 2.0 and a dose-response relationship is observed. Percentage of genotoxicity inhibition ( $\%$ GI) was calculated as indicated in Materials and Methods. *, a significant increase $(\mathrm{p}<0.05)$ in negative control was found using the Student $t$-test. **, a significant reduction $(\mathrm{p}<0.05)$ in positive control was found using Student $t$-test. n.s., no significant differences were found. 
cutaneous permeation (Aqil et al., 2007; Sapra et al., 2008), the simultaneous use of either of these compounds together with citral in gel preparation, should be an effective approach for skin chemoprotection. However, cytotoxicity in human fibroblast cells has been reported at concentrations higher than $1 \%$ of citral (Hayes and Marcovic, 2002). Moreover, lemongrass (Cymbopogon citratus) EO with a high citral content (70\%-90\%) induced phototoxic effects in murine fibroblastic cell-line 3T3 and rabbit cornea derived cell-line SIRC (Dijoux et al., 2006). Thus, further studies on skin sensitization and phototoxicity with terpenoids are required.

Based on data from the literature (Pino-Alea et al., 1996; Abad et al., 1997; Viana et al., 1998, 2000; Vale et al., 1999; Pascual et al., 2001b; Zétola et al., 2002, Gazola et al., 2004; Andrighetti-Fröhner et al., 2005; TeixeiraDuarte et al., 2005; de Carvalho and da Fonseca, 2006; Sena-Filho et al., 2006; Paduch et al., 2007; Hennebelle et al., 2008a,b; Ara et al., 2009; Arruda et al., 2009; MesaArango et al., 2009), L. alba clearly has a wide-ranging therapeutic potential, even further amplified by the antigenotoxic properties against bleomycin, as a source of compounds with application in cancer chemoprevention. As indicated above, citral, carvone and limonene have shown protective properties in vitro and in vivo (Connor, 1991; He et al., 1997; Crowell, 1999; Uedo et al., 1999; Nakamura et al., 2003; de Carvalho and da Fonseca, 2006; Paduch et al., 2007; Seo et al., 2008; Patil et al., 2009; Rabi and Bishayee, 2009; Shukla et al., 2009), all of which highlight the potential benefit of $L$. alba and its major components, citral, carvone and limonene, as dietary supplements with chemopreventive and/or antioxidant properties.

In conclusion, this study showed the antigenotoxic properties of $L$. alba EO, citral, carvone and limonene against the drug bleomycin, lending support to the potential of the oils and compounds in chemoprevention and cancer therapy. Since the role of chemopreventive agents in the etiology of cancer is very complex, and involves several modes of action, and our results concern only in vitro experiments with a bacterial assay, additional animal and human studies involving different endpoints should be addressed in order to clarify the antimutagenic potential of $L$. alba EOs and their major constituents. In addition, harmonized studies on the genotoxicity of citral, carvone and limonene, using a battery of in vivo assays that evaluate different levels of DNA damage expression, are required, prior to the practical use of these compounds in chemoprevention.

\section{Acknowledgments}

The authors wish to thank Dr. José Luis Fernández Alonso for botanical identification of specimens and Dr. Montserrat Llagostera Casal from the Universidad Autónoma de Barcelona for gently supplying the PQ37 E. coli strain. This work was supported by the Vice-Rectory for
Scientific Research at the Universidad Industrial de Santander (UIS, Grant 5154), and by the Colombian Institute of Science and Technology, CENIVAM-COLCIENCIAS (Grant RC-432-2004).

\section{References}

Abad MJ, Bermejo P, Villar A, Sanchez-Palomino S and Carrasco L (1997) Antiviral activity of medicinal plant extracts. Phytother Res 11:198-202.

Andrighetti-Fröhner CR, Sincero TCM, da Silva AC, Savi LA, Gaido CM, Bettega JMR, Mancini M, de Almeida MTR, Barbosa RA, Farias MR, et al. (2005) Antiviral evaluation of plants from Brazilian Atlantic Tropical Forest. Fitoterapia 76:374-378

Aqil M, Ahad A, Sultana Y and Ali A (2007) Status of terpenes as skin penetration enhancers. Drug Discov Today 12:10611067.

Ara N, Nur MH, Amran MS, Wahid MII and Ahmed M (2009) In vitro antimicrobial and cytotoxic activities of leaves and flowers extracts from Lippia alba. Pak J Biol Sci 12:87-90.

Arruda DC, Miguel DC, Yokoyama-Yusunaka JKU, Katzin AM and Uliana SRB (2009) Inhibitory activity of limonene against Leishmania parasites in vitro and in vivo. Biomed Pharmacother 63:643-649.

Burt S (2004) Essential oils: Their antibacterial properties and potential applications in foods - A review. Int J Food Microbiol 94:223-253

Connor MJ (1991) Modulation of tumor promotion in mouse skin by the food additive citral (3, 7-dimethyl-2, 6-octadienal). Cancer Lett 56:25-28.

Crowell PL (1999) Prevention and therapy of cancer by dietary monoterpenes. J Nutr 129:775S-778S

Claussen CA and Long EC (1999) Nucleic acid recognition by metal complexes of bleomycin. Chem Rev99:2797-2816.

de Carvalho CCCR and da Fonseca MMR (2006) Carvone: Why and how should one bother to produce this terpene. Food Chem 95:413-422.

Dijoux N, Guingand Y, Bourgeois C, Durand S, Fromageot C, Combe $\mathrm{C}$ and Ferret PJ (2006) Assessment of the phototoxic hazard of some essential oils using modified 3T3 neutral red uptake assay. Toxicol in Vitro 20:480-489.

du Plooy W, Regnier T and Combrinck S (2009) Essential oil amended coatings as alternatives to synthetic fungicides in citrus postharvest management. Postharvest Biol Tech 53:117-122.

Franzios G, Mirotsou M, Hatziapostolou E, Kral J, Scouras ZG and Mavragani-Tsipidou P (1997) Insecticidal and genotoxic activities of mint essential oils. J Agr Food Chem 45:2690-2694.

Fuentes JL, Vernhe M, Cuetara EB, Sánchez-Lamar A, Santana JL and Llagostera M (2006) Tannins from barks of Pinus caribeae Morelet protect Escherichia coli cells against DNA damage induced by $\gamma$-rays. Fitoterapia 77:116-120.

Gazola R, Machado D, Ruggiero C, Singi G and Alexandre MM (2004) Lippia alba, Melissa officinalis and Cymbopogon citratus: Effects of the aqueous extracts on the isolated hearts of rats. Pharmacol Res 50:477-480.

Gomes-Carneiro MR, Viana MES, Felzenszwalb I and Paumgartten FJR (1998) Mutagenicity testing of $( \pm)$-camphor, 
1,8-cineole, citral, citronellal, (-)-menthol and terpineol with the Salmonella/microsome assay. Mutat Res 416:129-136.

Hayes AJ and Marcovic B (2002) Toxicity of Australian essential oil Backhousia citriodora (Lemon myrtle). Part 1. Antimicrobial activity and in vitro cytotoxicity. Food Chem Toxicol 40:535-543.

He L, Mo H, Hadisusilo S, Qureshi AA and Elson CE (1997) Isoprenoids suppress the growth of murine B16 melanomas in vitro and in vivo. J Nutr 127:668-674.

Hennebelle T, Sahpaz S, Dermont C, Joseph H and Bailleul F (2006) The essential oil of Lippia alba: Analysis of samples from French overseas departments and review of previous works. Chem Biodiv 3:1116-1125.

Hennebelle T, Sahpaz S, Joseph H and Bailleul F (2008a) Ethnopharmacology of Lippia alba. J Ethnopharmacol 116:211222.

Hennebelle T, Sahpaz S, Gressier B, Joseph H and Bailleul F (2008b). Antioxidant and neurosedative properties of polyphenols and iridoids from Lippia alba. Phytother Res 22:256-258.

Kovats E (1965) Gas chromatographic characterization of organic substances in the retention index system. Adv Chrom 1:229-247.

Linde JH, Combrinck S, Regnier TJC and Virijevic RS (2009) Chemical composition and antifungal activity of the essential oils of Lippia rehmannii from South Africa. S Afr J Bot 76:37-42.

Mesa-Arango AC, Montiel-Ramos J, Zapata B, Duran C, Betancur-Galvis L and Stashenko E (2009) Citral and carvone chemotypes from the essential oils of Colombian Lippia alba (Mill.) N.E. Brown: Composition, cytotoxicity and antifungal activity. Mem Inst Oswaldo Cruz 104:878-884.

Nakamura Y, Miyamoto M, Murakami A, Ohigashi H, Osawa T and Uchida K (2003) A phase II detoxification enzymes inducer from lemongrass: Identification of citral and involvement of electrophilic reaction in the enzyme induction. Biochem Biophys Res Commun 302:593-600.

Oliveira DR, Leitão GG, Santos SS, Bizzo HR, Lopes D, Alvino CS, Alvino DS and Leitão SG (2006) Ethnopharmacological study of two Lippia species from Oriximiná, Brazil. J Ethnopharmacol 108:103-108.

Paduch R, Kandefer-Szerszen K, Trytek M and Fiedurek J (2007) Terpenes: Substances useful in human healthcare. Arch Immunol Ther Exp 55:315-327.

Pascual ME, Slowing K, Carretero E, Sánchez-Mata D and Villar A (2001a) Lippia: Traditional uses, chemistry and pharmacology: A review. J Ethnopharmacol 76:201-214.

Pascual ME, Slowing K, Carretero ME and Villar A (2001b). Antiulcerogenic activity of Lippia alba (Mill.) N.E. Brown (Verbenaceae). IL Farmaco 56:501-504.

Patil JR, Jayaprakasha GK, Chindambara-Murthy KN, Tichy SE, Chetti MB and Patil BS (2009) Apoptosis-mediated proliferation inhibition of human colon cancer cells by volatile principles of Citrus aurantifolia. Food Chem 114:1351-1358.

Pino-Alea JA, Ortega-Luis AG, Rosado-Pérez A, Rodriguez-Jorge $\mathrm{M}$ and Baluja R (1996) Composición y propiedades antibacterianas del aceite esencial de Lippia alba (Mill.) N.E. Brown. Rev Cubana Farm 30:29-35.

Quillardet P, Huisman O, D'Ari R and Hofnung M (1982) SOS Chromotest, a direct assay of induction of an SOS function in Escherichia coli K-12 to measure genotoxicity. Proc Natl Acad Sci USA 79:5971-5975.

Rabi T and Bishayee A (2009) Terpenoids and breast cancer chemoprevention. Breast Cancer Res Treat 115:223-239.

Rojas-Graü MA, Avena-Bustillos RJ, Olsen C, Friedman M, Henika PR, Martí-Belloso O, Pan Z and McHugh TH (2007) Effect of plant essential oils and oil compounds on mechanical barrier and antimicrobial properties of alginate-apple puree edible films. J Food Eng 81:634-641.

Sapra B, Jain S and Tiwary AK (2008) Percutaneous permeation enhancement by terpenes: Mechanistic view. AAPS J 10:120-132.

Sena-Filho JG, Melo JGS, Saraiva AM, Goncalves AM, Caetano-Psiottano MN and Xavier HS (2006) Antimicrobial activity and phytochemical profile from the roots of Lippia alba (Mill.) N.E. Brown. Rev Bras Farmacogn 16:506-509.

Seo KA, Kim H, Ku HY, Ahn HJ, Park SJ, Bae SK, Shin JG and Liu KH (2008) The monoterpenoids citral and geraniol are moderate inhibitors of CYP2B6 hydroxylase activity. Chem Biol Interact 174:141-146.

Shukla R, Kumar A, Singh P and Dubey NK (2009) Efficacy of Lippia alba (Mill.) N.E. Brown essential oil and its monoterpenes aldehyde constituents against fungi isolated from some edible legume seeds and aflatoxin $\mathrm{B}_{1}$ production. Int $\mathrm{J}$ Food Microbiol 135:165-170.

Stammati A, Bonsi P, Zucco F, Moezelaar R, Alakomi HL and von Wright A (1999) Toxicity of selected plant volatiles in microbial and mammalian short-term assays. Food Chem Toxicol 37:813-823.

Stashenko EE, Jaramillo BE and Martínez JR (2003) Comparación de la composición química y de la actividad antioxidante in vitro de los metabolitos secundarios volátiles de plantas de la familia Verbenaceae. Rev Acad Col Cien 27:579-597.

Stashenko EE, Jaramillo BE and Martínez JR (2004) Comparison of different extraction methods for the analysis of volatile secondary metabolites of Lippia alba (Mill.) N.E. Brown, grown in Colombia and evaluation of its in vitro antioxidant activity. J Chromatogr A 1025:93-103.

Stashenko EE, Ruiz C, Muñoz A, Castañeda M and Martínez J (2008) Composition and antioxidant activity of essential oils of Lippia origanoides HBK grown in Colombia. Nat Prod Commun 3:563-566.

Teixeira-Duarte MC, Figueira GM, Sartoratto A, García-Rehder VL and Delarmelina C (2005) Anti-Candida activity of Brazilian medicinal plants. J Ethnopharmacol 97:305-311.

Teixeira-Duarte MC, Leme EE, Delarmelina C, Soarces AA, Figueira GM and Sartoratto A (2007) Activity of essential oils from Brazilian medicinal plants on Escherichia coli. J Ethnopharmacol 111:197-201.

Uedo N, Tasuta M, Iishi H, Baba M, Sakai N, Yano H and Otani T (1999) Inhibition by D-limonene of gastric carcinogenesis induced by $N$-methyl- $N$-nitro- $N$-nitrosoguanidine in Wistar rats. Cancer Lett 137:131-136.

Vale TG, Matos FJA, de Lima TCM and Viana GSB (1999) Behavioral effects of essential oils from Lippia alba (Mill.) N.E. Brown chemotypes. J Ethnopharmacol 167:127-133.

Viana GSB, Vale TG, Rao VSN and Matos FJA (1998) Analgesic and anti-inflammatory effects of two chemotypes of Lippia alba: A comparative study. Pharm Biol 36:347-351. 
Viana GSB, Vale TG, Silva CMM and Matos FJA (2000) Anticonvulsant activity of essential oils and active principles from chemotypes of Lippia alba (Mill.) N.E. Brown. Biol Pharm Bull 23:1314-1317.

Vicuña GC, Stashenko EE and Fuentes JL (2010) Chemical composition of the Lippia origanoides essential oils and their antigenotoxicity against bleomycin-induced DNA damage. Fitoterapia 81:343-349.

Vukovic-Gacic B, Nikcevic S, Beric-Bjedov T, Knezevic-Vukcevic J and Simic D (2006) Antimutagenic effect of essential oil of sage (Salvia officinalis L.) and its monoterpenes against UV-induced mutations in Escherichia coli and Saccharomyces cerevisiae. Food Chem Toxicol 44:17301738.
Zétola M, de Lima TCM, Sonaglio D, González-Ortega G, Limberger RP, Petrovick PR and Bassani VL (2002) CNS activities of liquid and spray-dried extracts from Lippia alba Verbenaceae (Brazilian false melissa). J Ethnopharmacol 82:207-215.

Zoghbi MGB, Andrade EHA, Santos AS, Silva MHL and Maia JGS (1998). Essential oils of Lippia alba (Mill.) N.E. Brown growing wild in Brazilian Amazon. Flavour Fragr J 14:411414.

Associate Editor: Catarina S. Takahashi

License information: This is an open-access article distributed under the terms of the Creative Commons Attribution License, which permits unrestricted use, distribution, and reproduction in any medium, provided the original work is properly cited. 